\section{Study the antimicrobial effects of chitosan-based edible film containing the Trachyspermum ammi essential oil on shelf-life of chicken meat}

Fatemeh Karimnezhad, ${ }^{1}$

Vadood Razavilar, ${ }^{1}$ AmirAli Anvar, ${ }^{1}$

Soheyl Eskandari ${ }^{2}$

${ }^{1}$ Department of Hygiene, Science and Research Branch, Islamic Azad University, Tehran; ${ }^{2}$ National Nutrition and Food Technology Research Institute (NNFTRI), Shahid Behesti University of Medical Sciences - Food and Drug Laboratory Research Center (FDLRC), Food and Drug Administration (FDA) Ministry of Health and Medical Education (MoH+ME), Tehran, Iran

\begin{abstract}
Packaging using chitosan-based edible films incorporated with natural essential oils is a safe and economic way to increase the shelf-life and acceptability of food products and especially chicken meat. Trachyspermum ammi is a natural medicinal plant with high antimicrobial effects cultivated in Iran. The present research was done to study the antimicrobial effects of chitosan-based edible film containing $T$. ammi essential oil on shelf-life of chicken meat. T. ammi fruits were collected and dried. Essential oil was extracted from plants using the Clevenger's apparatus. High molecular weight chitosan with $1 \%$ and $2 \%$ concentrations of $T$. ammi essential oil were used for coating of chicken fillets. Treatments were stored at $4^{\circ} \mathrm{C}$ for 12 days. Count of the total aerobic, total psychrophilic and coliform bacteria had ranges of $3.8 \pm 0.25$ to $8.32 \pm 0.26, \quad 4 \pm 0.23$ to $8.65 \pm 0.28$ and $1.8 \pm 0.09$ to $5.62 \pm 0.16 \mathrm{CFU} / \mathrm{g}$ during the storage period. Antimicrobial effects were significantly increased with the incorporation of $T$. ammi essential oil $(\mathrm{P}<0.05)$. Antimicrobial effects were also depended on the concentration of T. ammi essential oil $(\mathrm{P}<0.05)$. Chitosan film incorporated with $2 \%$ T. ammi essential oil had the highest inhibitory effects on total aerobic, total psychrophilic and coliform bacteria $(\mathrm{P}<0.05)$. Our results pointed out that the incorporation of T. ammi essential oil at $2 \%$ concentration has potential for using the developed chitosan edible film as an active packaging of chicken meat.
\end{abstract}

\section{Introduction}

Antimicrobial resistance is become the most emerging issue facing food producing factories to increase the shelf-life of their products. ${ }^{1,2}$ Application of synthetic antimicrobial agents to increase the shelf-life of various types of foods is also failed due to their high mutagenic, carcinogenic, allergenic and toxic effects. ${ }^{3,4}$ Therefore, food producing factories have gravitated to use from natural antimicrobial agents as edible films to prevent from the spoilage and also increase the shelf-life of food products. 5,6 Edible coatings are thin layers of edible materials like proteins, polysaccharides and lipids formed as coatings on food stuffs which can rise the shelf-life of foods because of their antimicrobial effects. ${ }^{7}$ It is used for preparation of the optimal moisture and atmosphere of the food product and prevent from the entry of foreign materials. ${ }^{7}$

Chitosan, deacetylated derivative of chitin, is a cationic polysaccharide consisting of (1,4)-linked-2- amino-deoxy-b-Dglucan. ${ }^{8}$ It is considered as a Generally Recognized as Safe (GARS) food additive and has been approved by the United States Food and Drug Administration (USFDA). ${ }^{9}$ Chitosan is also known as strong antimicrobial, antioxidant, anti-inflammatory, antihypertensive, antidiabetic, anticoagulant, antiallergic, antiobesity and anticancer agent. ${ }^{10}$ Documented data revealed that chitosan is one of the most appropriate biopolymer for production of edible films and coatings. ${ }^{11}$ Biocompatibility, non-toxicity, biodegradability and film-forming abilities of chitosan make it suitable in food preservation. ${ }^{10,11}$ Recently, food producing factories have attracted to use from chitosan-based edible films enriched with natural antimicrobial and antioxidant components like plant extracts and essential oils.

Trachyspermum ammi (T. ammi) or Bishop's weed, Carom seed and ajowan is an erect annual herb belonging to the family Apiaceae. It is cultivated in Egypt, Iran, Iraq, Pakistan, Afghanistan and India. Its fruit have a bitter and pungent taste and used as flavor and preservation in foods. ${ }^{12,13}$ It is full of medicinal essential oil with high percent of thymol. ${ }^{12,13}$ T. ammi is traditionally used as antimicrobial, antifungal, antiviral, antipyretic, anti-inflammatory, analgesic, antifilarial, anti-nociceptive and antioxidant agent. ${ }^{12,13}$ It is used as a traditional potential herb for curing various diseases in humans and animals like gastrointestinal disorders. ${ }^{12,13}$

In despite of the high antimicrobial effects of chitosan and T. ammi essential oil, there were no previously published data on their application as an edible film.
Correspondence: Vadood Razavilar, Department of Hygiene, Science and Research Branch, Islamic Azad University, Tehran, Iran. Tel.: +98.912.1026502.

E-mail: V.razavii@yahoo.com

Key words: Chitosan edible film, Trachyspermum ammi, Essential oil, Coating, Chicken meat, Shelf-life.

Acknowledgements: Author would like to thanks from the staffs of the Food Science and Technology and also Medicinal Plants Research Centers of the Islamic Azad University, Science and Research Branch, Tehran, Iran for their important technical supports.

Contributions: the authors contributed equally

Conflict of interest: the authors declare no potential conflict of interest.

Received for publication: 14 May 2017. Accepted for publication: 5 June 2017.

This work is licensed under a Creative Commons Attribution NonCommercial 4.0 License (CC BY-NC 4.0).

(C) Copyright F. Karimnezhad et al., 2017

Licensee PAGEPress, Italy

Microbiology Research 2017; 8:7226

doi:10.4081/mr.2017.7226

Therefore, the present investigation was done in order to study the antimicrobial effects of chitosan-based edible film containing the T. ammi essential oil on shelflife of chicken meat.

\section{Materials and Methods}

\section{Plants}

From July to September 2015, fruits of T. ammi were collected at ripening from wild plants growing in Shiraz, Iran. A voucher specimen was identified and deposited in the Herbarium of the University of Tehran, Iran, under the code $125 / 21224 / 2012$.

\section{Essential oil}

Essential oil was extracted by hydrodistillation using Clevenger's apparatus. Dried plant material $(50 \mathrm{~g})$ was crushed to powder and placed into flasks $(1 \mathrm{~L})$ with sterile water $(250 \mathrm{~mL})$ at $70^{\circ} \mathrm{C}$. After $3 \mathrm{~h}$ the oil was isolated and dried over anhydrous sodium sulphate (Merck, Germany). ${ }^{14}$ Extracted essential oil was kept in screw 
capped bottles at $4^{\circ} \mathrm{C}$ for further application.

\section{Preparation of edible film}

Chitosan film was prepared by dissolving high molecular weight chitosan (800,000 cps; $>75 \%$ deacetylation degree) (Sigma-Aldrich, USA) in an aqueous solution $(1 \% \mathrm{v} / \mathrm{v})$ of acetic acid (Merck, Germany) to a concentration of $2 \%(\mathrm{w} / \mathrm{v})$ while stirring on a magnetic stirrer-hot plate. The solution was stirred with low heat (at $45^{\circ} \mathrm{C}$ ) which typically required $3 \mathrm{~h}$ stirring. The resultant chitosan solution was filtered through a Whatman No. 3 filter paper and followed by vacuum filtration to eliminate insoluble and remove any undissolved particles. Glycerol (Sigma-Aldrich, USA) was added as $30 \%(\mathrm{w} / \mathrm{w})$ of the total solid weight in solution. Tween 80 at level of $0.25 \%(\mathrm{v} / \mathrm{v})$ was added in film forming solutions to assist essential oil dissolution. $\mathrm{pH}$ of solution was set at 5.8 using the $\mathrm{NaOH}$ (Merck, Germany). Essential oil of T. ammi was added to the chitosan solution to reach a final concentration of $1 \%$ and $2 \%$ (w/w). The solution was homogenized (IKA T25 basic, Staufen, Germany) at $8000 \mathrm{rpm}$ for $3 \mathrm{~min}$ to obtain an emulsion. The mixtures were cast on to flat, level polytetrafluoroethylene casting plate. After drying the films at room temperature for at least $36 \mathrm{~h}$, they were peeled from the plates. Dried films were conditioned at $50 \% \mathrm{RH}$ and 25 ${ }^{\circ} \mathrm{C}$ for $48 \mathrm{~h}$ prior to testing. ${ }^{15}$

\section{Chicken meat samples preparation}

Chicken fillet samples were taken from the slaughterhouses of Tehran province, Iran (400 g pieces, $7 \mathrm{~cm}$ diameter, $15 \mathrm{~cm}$ length). All meat samples were surrounded and packaged using the prepared chitosanbased edible films containing the T. ammi essential oil. All treatments (chicken fillet coated with chitosan free essential oil film (chitosan group), chicken fillet coated with chitosan film containing the $1 \%$ T. ammi essential oil (chitosan with $1 \% \quad$. ammi essential oil), chicken fillet coated with chitosan film containing the $2 \%$ T. ammi essential oil (chitosan with $1 \%$ T. ammi essential oil) and chicken fillet without any packaging (control group) were kept at $4{ }^{\circ} \mathrm{C}$ and tested at days of $0,3,6,9$ and 12 after packaging.

\section{Microbial examinations}

Ten grams of each sample were transferred aseptically to a sterile stomacher bag containing $90 \mathrm{~mL}$ of peptone water (Merck, Germany) and homogenized in a stomacher (IUL Instrument, Spain) for up to 2 min. Subsequent serial decimal dilutions of the samples were made using peptone water (Merck, Germany), as required. Selective agar plates were inoculated with $0.1 \mathrm{~mL}$ of the appropriate dilutions. Aerobic Plate Counts (APC) were taken in quadruplicates using the spread-plate method in Plate count agar (Merck, Germany) following the incubations at $37^{\circ} \mathrm{C}$ for $24 \mathrm{~h}$ and 48 h. ${ }^{16}$ Coliform Counting (CC) was done using the pour plate inoculation of samples into the Violet Red Bile Agar (VRBA, Merck, Germany) following the incubations at $35 \pm 2^{\circ} \mathrm{C}$ for $48 \mathrm{~h}$. Suspected colonies were transferred into the Brilliant Green Broth (Merck, Germany) and incubated at $35 \pm 2{ }^{\circ} \mathrm{C}$ for $24-48$ h. ${ }^{16}$ Total Psychrophilic Count (TPC) was done similar to the APC but inoculated media were incubated at $7^{\circ} \mathrm{C}$ for 7-10 days. ${ }^{16}$

\section{Statistical analysis}

All tests were done 3 times. Data were presented as mean \pm Standard Deviation (SD). Data were analyzed using the SPSS software (SPSS Inc, Chicago, IL. v. 22.0). Significance levels $(\mathrm{P}<0.05)$ were assessed by ANOVA and supplementary Turkey HSD tests.

\section{Results}

Table 1 represents the levels of APC for various treatments of chicken fillet on maintenance period. The numbers of total aerobic bacteria had a range of $3.8 \pm 0.25$ to $8.32 \pm 0.26 \mathrm{CFU} / \mathrm{g}$ during the maintenance period. We found that the count of aerobic bacteria was increased in control and chitosan groups during the maintenance period. Count of aerobic bacteria in groups of chicken fillet treated with chitosan with $1 \%$ T. ammi essential oil and also those of chitosan with $1 \% T$. ammi essential oil were decreased up to the $6^{\text {th }}$ days of maintenance and then increased. Statistically significant differences were seen for the APC of chicken fillet on $3^{\text {rd }}, 6^{\text {th }}, 9^{\text {th }}$ and $12^{\text {th }}$ days of maintenance between control and treatment groups.

Table 2 represents the levels of TPC for various treatments of chicken fillet on maintenance period. The numbers of total psychrophilic bacteria had a range of $4 \pm 0.23$ to $8.65 \pm 0.28 \mathrm{CFU} / \mathrm{g}$ during the maintenance period. We found that the count of psychrophilic bacteria was

Table 1. Levels of aerobic plate count for various treatments of chicken fillet on maintenance period.

\begin{tabular}{lccccc} 
Treatments & \multicolumn{4}{c}{ Aerobic plate count in 12 days of maintenance (CFU/g) } \\
& 0 & 3 & 6 & 9 & 12 \\
Control & $4.22 \pm 0.27^{\mathrm{a}}$ & $5.03 \pm 1.05^{\mathrm{a}}$ & $6.16 \pm 0.42^{\mathrm{a}}$ & $6.95 \pm 0.9^{\mathrm{a}}$ & $8.32 \pm 0.26^{\mathrm{a}}$ \\
Chitosan & $4.01 \pm 0.09^{\mathrm{a}}$ & $4.52 \pm 0.27^{\mathrm{b}}$ & $5.21 \pm 0.24^{\mathrm{b}}$ & $6.17 \pm 0.17^{\mathrm{a}}$ & $7.34 \pm 0.18^{\mathrm{b}}$ \\
\hline Chitosan with 1\% T.ammi essential oil & $3.9 \pm 0.16^{\mathrm{a}}$ & $3.73 \pm 0.40^{\mathrm{b}}$ & $4.01 \pm 0.22^{\mathrm{c}}$ & $4.58 \pm 0.34^{\mathrm{b}}$ & $4.74 \pm 0.52^{\mathrm{c}}$ \\
Chitosan with 1\% T.ammi essential oil & $3.8 \pm 0.25^{\mathrm{a}}$ & $3.53 \pm 0.39^{\mathrm{b}}$ & $3.81 \pm 0.17^{\mathrm{c}}$ & $4.38 \pm 0.22^{\mathrm{b}}$ & $4.56 \pm 0.19^{\mathrm{c}}$ \\
\hline *Dissimilar letters in each column showed. & & & & &
\end{tabular}

Table 2. Levels of total psychrophilic count for various treatments of chicken fillet on maintenance period.

\begin{tabular}{|c|c|c|c|c|c|}
\hline \multirow[t]{2}{*}{ Treatments } & \multicolumn{5}{|c|}{ Total psychrophilic count in 12 days of maintenance (CFU/g) } \\
\hline & 0 & 3 & 6 & 9 & 12 \\
\hline Control & $4.59 \pm 0.2^{\mathrm{a}^{*}}$ & $5.21 \pm 0.23^{a}$ & $6.68 \pm 0.19$ a & $7.35 \pm 0.16^{\mathrm{a}}$ & $8.65 \pm 0.28^{a}$ \\
\hline Chitosan & $4.45 \pm 0.08^{a}$ & $4.72 \pm 0.16^{b}$ & $5.22 \pm 0.25^{b}$ & $6.48 \pm 0.27^{b}$ & $8.32 \pm 0.25^{\mathrm{a}}$ \\
\hline Chitosan with $1 \%$ T. ammi essential oil & $4.18 \pm 0.19 \mathrm{ab}$ & $3.51 \pm 0.11^{c}$ & $4.15 \pm 0.1^{\mathrm{c}}$ & $4.28 \pm 0.14^{c}$ & $4.73 \pm 0.17^{b}$ \\
\hline Chitosan with $1 \%$ T. ammi essential oil & $4 \pm 0.23 \mathrm{~b}$ & $3.54 \pm 0.14^{\mathrm{c}}$ & $3.37 \pm 0.08^{d}$ & $4.38 \pm 0.1^{c}$ & $4.59 \pm 0.18^{b}$ \\
\hline
\end{tabular}

*Dissimilar letters in each column showed significant statistical difference about $\mathrm{P}<0.05$. 
increased in control and chitosan groups during the maintenance period. Count of psychrophilic bacteria in groups of chicken fillet treated with chitosan with $1 \%$ T. ammi essential oil were decreased up to the $6^{\text {th }}$ days of maintenance and then increased, while those of chitosan with $2 \%$ T. ammi essential oil were decreased up to the $9^{\text {th }}$ days of maintenance and then increased. Statistically significant differences were seen for the TPC of chicken fillet on $3^{\text {rd }}, 6^{\text {th }}$, $9^{\text {th }}$ and $12^{\text {th }}$ days of maintenance between control and treatment groups.

Table 3 represents the levels of $\mathrm{CC}$ for various treatments of chicken fillet on maintenance period. The numbers of total coliform bacteria had a range of $1.8 \pm 0.09$ to $5.62 \pm 0.16 \mathrm{CFU} / \mathrm{g}$ during the maintenance period. We found that the count of coliform bacteria was increased in control and chitosan groups during the maintenance period. Count of coliform bacteria in groups of chicken fillet treated with chitosan with $1 \%$ and also $2 \% T$. ammi essential oil were equal in days of 0 and 3. CC in group of fillet chicken treated with chitosan with $1 \% T$. ammi essential oil was decreased in a day of 6 and then increased, while that of $2 \% T$. ammi essential oil was decreased in days of 6 and 9 and then increased. Statistically significant differences were seen for the $\mathrm{CC}$ of chicken fillet on $3^{\text {rd }}, 6^{\text {th }}, 9^{\text {th }}$ and $12^{\text {th }}$ days of maintenance between control and treatment groups.

\section{Discussion}

The present investigation revealed that chitosan-based edible film with $T$. ammi essential oil especially on $2 \%$ concentration had considerable antimicrobial effects on chicken fillet. We found that coating of chicken fillet with chitosan film containing $2 \%$ T. ammi essential oil caused decrease in the numbers of total aerobic, total psychrophilic and coliform bacteria which make it suitable for coating of chicken fillet.

Chitosan is mainly caused destruction of the membrane of bacteria. Electrostatic forces in the structure of chitosan between the $\mathrm{NH}^{+3}$ groups and the negative residues which compete with the $\mathrm{Ca}^{2+}$ for electronegative sites on the membrane surface caused changes in the permeability of membrane wall. ${ }^{17}$ This changes cause provokes internal osmotic imbalances and consequently prevent from the growth of bacteria. It is also cause hydrolysis of the peptidoglycans in the microorganism wall, leading to the leakage of intracellular electrolytes such as potassium ions and other low molecular weight components such as proteins, nucleic acids, glucose, and lactate dehydrogenase. ${ }^{17}$ Binding of chitosan with microbial DNA, which leads to the inhibition of the mRNA and protein synthesis is another mechanism for the antimicrobial effects of chitosan. ${ }^{17}$ It is also act by chelation of metals, suppression of spore elements and binding to essential nutrients to microbial growth. ${ }^{17}$ In keeping with this, documented data revealed that chitosan has only bacteriostatic effects. ${ }^{17}$ Therefore, there is demand for using from a bactericidal agents besides the chitosan. T. ammi essential oil was our choice in this study.

T. ammi fruits yield $2 \%$ to $4 \%$ essential oil, with thymol as the main component (35\% to $60 \%$ ). Other detected components in the essential oil of the $T$. ammi fruits are $\gamma$-terpenine, para-cymene, dipentene, $\alpha$ - and $\beta$-pinenes, $\alpha$-terpinene, carvone, carvacrol, diallapiole, camphene, limonene, myrcene and $\alpha$-3-carene. ${ }^{18,19}$ Documented data revealed that all of these chemical components have considerable antimicrobial effects on various types of bacteria which guaranties the high antimicrobial effects of T. ammi essential oil. ${ }^{18,19}$

Unfortunately, there were no previously published data on the antimicrobial effects of chitosan-based edible film with T. ammi essential oil on shelf-life of chicken fillet. In a similar study which was conducted by Mehdizadeh et al. ${ }^{9}$ Thymus kotschyanus essential oil was used with chitosan film. They showed that antimicrobial effects of edible films meaningfully increased with the incorporation of essential oil which was similar to our findings. They showed considrabel antimicrobial effects of the Chitosan-T. kotschyanus edible film on Listeria monocytogenes, Staphylococcus aureus and Escherichia coli 0157:H7 bacteria. Quesada et al. ${ }^{20}$ reported the high antimicrobial effects of the chitosan films with Thymus vulgaris 1. essential oil for ready-to-eat meat. They showed that addition of T. vulgaris in the films caused reduction if the yeast population, while had no reduction effects on the population of lactic acid bacteria, aerobic mesophilic bacteria and enterobacteria. Considerable antimicrobial effects of chitosan-based edible films containing various types of natural essential oil have also been reported previously. ${ }^{21}$ Hassanshahian et al. ${ }^{22}$ reported that T. ammi essential oil had a high antimicrobial effects on E. coli, Klebsiella pneumoniae and $S$. aureus. They revealed that the highest Minimum Inhibitory Concentration (MIC) of $T$. ammi essential oil were found for $E$. coli (100 ppm) and K. pneumoniae (250 ppm). These pathogenic bacteria can act as putrefactive agents in meat. Vitali et al. ${ }^{23}$ reported that T. ammi essential oil inhibited from the proliferation of the Gram-positive bacteria and especially $S$. aureus. Among Gram-negative bacteria, only E. coli was susceptible to T. ammi essential oil.

\section{Conclusions}

In conclusion, an antibacterial chitosanbased edible film incorporated with T. ammi essential oil is promising and has good potential to enhance the safety and also shelf-life of chicken fillet. We recommended using from chitosan film with $2 \% T$. ammi essential oil for coating of the chicken fillet which is supposed to be kept for a short time (12 days) at refrigerator. Future investigation could be conducted to assess the sensory and physicochemical properties of coated chicken fillet as well as to describe the stability of produced films.

Table 3. Levels of coliform count for various treatments of chicken fillet on maintenance period.

\begin{tabular}{|c|c|c|c|c|c|}
\hline \multirow[t]{2}{*}{ Treatments } & \multicolumn{5}{|c|}{ Coliform count in 12 days of maintenance (CFU/g) } \\
\hline & 0 & 3 & 6 & 9 & 12 \\
\hline Control & $2.14 \pm 0.14^{\mathrm{a}}$ & $3 \pm 0.11^{\mathrm{a}}$ & $4.17 \pm 0.17^{\text {a }}$ & $4.88 \pm 0.16^{\mathrm{a}}$ & $5.62 \pm 0.16^{\text {a }}$ \\
\hline Chitosan & $2 \pm 0.11$ ab & $2.38 \pm 0.09 \mathrm{~b}$ & $2.94 \pm 0.12^{b}$ & $3.69 \pm 0.19 \mathrm{~b}$ & $4.97 \pm 0.11^{b}$ \\
\hline Chitosan with $1 \%$ T. ammi essential oil & $1.89 \pm 0.09$ a & $1.89 \pm 0.07^{\mathrm{c}}$ & $1.54 \pm 0.09^{\mathrm{c}}$ & $1.9 \pm 0.09 \mathrm{c}$ & $2.23 \pm 0.04^{c}$ \\
\hline Chitosan with 1\% T. ammi essential oil & $1.8 \pm 0.34^{b}$ & $1.8 \pm 0.09 \mathrm{c}$ & $1.08 \pm 0.04^{\mathrm{d}}$ & $1.53 \pm 0.07 \mathrm{~d}$ & $2.14 \pm 0.03^{c}$ \\
\hline
\end{tabular}

*Dissimilar letters in each column showed significant statistical difference about $\mathrm{P}<0.05$. 


\section{References}

1. Iulietto MF, Sechi P, Borgogni E, Cenci Goga BT. Antibiotic susceptibility profiles of ropy slime-producing Leuconostoc mesenteroides isolated from cooked meat products. Microbiol Res 2016;7:6519.

2. Hemmatinezhad B, Khamesipour F, Mohammadi M, et al. Microbiological investigation of O-serogroups, virulence factors and antimicrobial resistance properties of shiga toxin-producing Escherichia coli Isolated from Ostrich, Turkey and quail meats. J Food Safety 2015;35:491-500.

3. Malhotra B, Keshwani A, Kharkwal H. Antimicrobial food packaging: potential and pitfalls. Front Microbiol 2015;6: 611.

4. Claudio L. Our food: packaging \& public health. Environ Health Perspect 2012;120:a232-7.

5. Irkin R, Esmer OK. Novel food packaging systems with natural antimicrobial agents. J Food Sci Technol 2015;52: 6095-111.

6. Maftoonazad N, Badii F. Use of edible films and coatings to extend the shelf life of food products. Recent Pat Food Nutr Agric 2009;1:162-70.

7. Damania P, Patel P, Shaw R, et al. Development of antimicrobial packaging materials for food preservation using bacteriocin from Lactobacillus casei. Microbiol Res 2016;7:6622.

8. Elsabee MZ, Abdou ES. Chitosan based edible films and coatings: a review. Mater Sci Eng C Mater Biol Appl 2013;33:1819-41.

9. Mehdizadeh T, Tajik H, Razavi Rohani
SM, Oromiehie AR. Antibacterial, antioxidant and optical properties of edible starch-chitosan composite film containing Thymus kotschyanus essential oil. Vet Res Forum 2012;3:167-73.

10. Altiok D, Altiok E, Tihminlioglu F. Physical, antibacterial and antioxidant properties of chitosan films incorporated with thyme oil for potential wound healing applications. J Mater Sci Mater Med 2010;21:2227-36.

11. Zimoch-Korzycka A, Bobak L, Jarmoluk A. Antimicrobial and Antioxidant Activity of Chitosan/ Hydroxypropyl Methylcellulose FilmForming Hydrosols Hydrolyzed by Cellulase. Int J Mol Sci 2016;17:E1436.

12. Bairwa R, Sodha RS, Rajawat BS. Trachyspermum ammi. Pharmacogn Rev 2012;6:56-60.

13. Moein MR, Zomorodian K, Pakshir K, et al. Trachyspermum ammi (L.) sprague: chemical composition of essential oil and antimicrobial activities of respective fractions. J Evid Based Complementary Altern Med 2015;20:50-6.

14. Awadhesh K, Mishra RK, Srivastava S, et al. Role of phylogenetic analysis for anti-bacterial activity of essential oil of Trachyspermum ammi L. against water borne pathogens. Adv Environ Res 2011;5:1271-8.

15. Moradi M, Tajik H, Razavi Rohani S, Oromiehie A. Effectiveness of Zataria multifora Boiss essential oil and grape seed etract impregnated chitosan film on ready-to-eat mortadella-type sausages during refrigerated storage. J Sci food Agric 2011;91:2850-57.

16. APHA. Compendium of methods for the microbiological examination of foods, 3rd ed. American Public Health Association, Washington, DC. 1992.

17. Goy RC, de Britto D, Assis OBG. A review of the antimicrobial activity of chitosan. Polímeros 2009;19:241-7.

18. Gandomi H, Abbaszadeh S, Jebelli Javan A, Sharifzadeh A. Chemical constituents, antimicrobial and antioxidative effects of Trachyspermum ammi essential oil. J Food Process Preserv 2014;38:1690-5.

19. Abdel-Hameed ES, Bazaid SA, Zahrani $\mathrm{OA}$, et al. Chemical composition of volatile components, antimicrobial and anticancer activity of n-hexane extract and essential oil from Trachyspermum ammi L. seeds. Orients J Chem 2014;30:1653-62.

20. Quesada J, Sendra E, Navarro C, SayasBarberá E. Antimicrobial active packaging including chitosan films with Thymus vulgaris L. essential oil for ready-to-eat meat. Foods 2016;5:1-13.

21. Yuan G, Chen X, Li D. Chitosan films and coatings containing essential oils: The antioxidant and antimicrobial activity, and application in food systems. Food Res Int 2016;89:117-28.

22. Hassanshahian M, Bayat Z, Saeidi S, Shiri Y. Antimicrobial activity of Trachyspermum ammi essential oil against human bacterial. Int J Adv Biol Biomed Res 2014;2:18-24.

23. Vitali LA, Beghelli D, Biapa Nya PC, et al. Diverse biological effects of the essential oil from Iranian Trachyspermum ammi. Arab J Chem 2016;9:775-86. 